\title{
Assessment of Fire Fuel Load Dynamics in Shrubland Ecosystems in the Western United States Using MODIS Products
}

\author{
Zhengpeng Li ${ }^{1}$, Hua Shi ${ }^{2}{ }^{*} \mathbb{C}$, James E. Vogelmann ${ }^{3}$, Todd J. Hawbaker ${ }^{4} \mathbb{D}$ and Birgit Peterson ${ }^{3}$ \\ 1 Earth System Science Interdisciplinary Center, University of Maryland, College Park, MD 20740, USA; \\ lizhengpeng@jingtum.com \\ 2 AFDS, Contractor to the U.S. Geological Survey (USGS) Earth Resources Observation and Science Center, \\ Sioux Falls, SD 57198, USA \\ 3 U.S. Geological Survey (USGS), Earth Resources Observation and Science Center, Sioux Falls, SD 57198, USA; \\ vogelmann@usgs.gov (J.E.V.); bpeterson@usgs.gov (B.P.) \\ 4 U.S. Geological Survey (USGS), Geosciences and Environmental Change Science Center, \\ Denver, CO 80225, USA; tjhawbaker@usgs.gov \\ * Correspondence: hshi@contractor.usgs.gov; Tel.: +1-605-594-6050
}

Received: 10 May 2020; Accepted: 6 June 2020; Published: 12 June 2020

check for updates

\begin{abstract}
Assessing fire behavior in shrubland/grassland ecosystems of the western United States has proven especially problematic, in part due to the complex nature of the vegetation and its relationships with prior fire history events. Our goals in this study were (1) to determine if we can effectively leverage the high temporal resolution capabilities of current remote sensing systems such as the Moderate Resolution Imaging Spectroradiometer (MODIS) to improve upon shrub and grassland mapping and (2) to determine if these improvements alter and improve fire behavior model results in these grass- and shrub-dominated systems. The study focused on the shrublands and grasslands of the Owyhee Basin, which is located primarily in southern Idaho. Shrubland and grassland fuel load dynamics were characterized using Normalized Difference Vegetation Index (NDVI) and Net Primary Production (NPP) datasets (both derived from MODIS). NDVI shrub and grassland values were converted to biomass, and custom fire behavior fuel models were then developed to evaluate the impacts of surface fuel changes on fire behaviors. Results from the study include the following: (1) high intra- and interannual spectral variability characterized these shrubland/grassland ecosystems, and this spectral variability was highly correlated with climate variables, most notably precipitation; (2) fire activity had a higher likelihood of occurring in areas where the NDVI (and biomass) differential between spring and summer values was especially high; (3) the annual fuel loads estimated from MODIS NPP showed that live herbaceous fuel loads were closely correlated with annual precipitation; (4) estimated fuel load accumulation was higher on shrublands than grasslands with the same vegetation productivity; (5) the total fuel load on shrublands was impacted by shrubland age, and live woody fuel load was over $66 \%$ of the total fuel load; and (6) comparisons of simulated fire behavior and spread between dynamic and static fuel loads, the latter estimates being obtained from the operational and nationwide LANDFIRE program, showed clear differences in fire indices and fire burn areas between the dynamic fuel loads and the static fuel loads. Current standard fuel models appear to have bias in underestimating the fire spread and total burnable area.
\end{abstract}

Keywords: wildfire; MODIS; LANDFIRE; NDVI; grassland; shrubland; fuel dynamics 


\section{Introduction}

Over the past several decades, increases in wildland fire frequency, size, and severity have had major influences on ecological, economic, and social systems [1,2]. Of the 26.8 million hectares that burned in eleven western US states between 1984 and 2011, 70.9\% (19.0 million hectares) were located in grasslands and shrublands as recorded by the Monitoring Trends in Burn Severity (MTBS) project [3]. Despite the prevalence of fires in these western US shrubland/grassland ecosystems, relatively limited research has been done to assess the fire behavior characteristics of these ecosystems and the long-term shrubland/grassland changes that are occurring throughout the region. There is a pressing need to better assess and evaluate the changes of the shrubland/grassland ecosystems and their relationships with fire occurrence and risks [4]. Such assessment can provide managers with critical information for improved management in the shrubland/grassland ecosystems to maintain ecosystem sustainability and to help reduce the negative impacts of wildfires.

The Landscape Fire and Resource Management Planning Tools Project (LANDFIRE) [5,6] was established in association with the National Fire Plan by the U.S. Department of Agriculture Forest Service and the Department of Interior. This landscape-scale fire, ecosystem, and fuel assessment project generates and distributes nationwide 30-meter-resolution data products for fire hazard reduction, incident planning and support, and resource management. The existing LANDFIRE database includes vegetation composition and structure, surface and canopy fuel characteristics, historical fire regimes, and ecosystem status. LANDFIRE provides the most recent nationally consistent and detailed reference conditions for the existing vegetation cover and fire fuel structures, and the data are relevant and accessible to land managers. While LANDFIRE data have many potential uses and applications, one known area of weakness relates to how LANDFIRE characterizes shrublands and grasslands. Some of the shrubland/grassland mapping and fuel characterization problems are a direct result of lack of field reference information, and LANDFIRE is very dependent upon the availability of accurate and current field information $[5,7]$. Shrublands and grasslands tend to have less readily available field information than forests, which tend to be relatively data rich. Another aspect of shrublands and grasslands that has been problematic for LANDFIRE relates to the intra- and interannual spectral, phenological, and ecological variability inherent to these systems. Shrubland/grassland ecosystems change much from year to year, and from season to season, thereby making it difficult to accurately characterize fire fuels for any one given point in time. The combination of (1) the lack of field information and (2) the complexity of fire fuel characteristics in these regions has made applications of LANDFIRE data in shrubland/grassland ecosystems challenging.

LANDFIRE fuel data layers can be used for spatially explicit modeling of fire behavior and spread to support fire management decision making. Historically, the LANDFIRE fuel layers have been static, with periodic updates, but for the most part, the intra- and interannual variability in fuel loads have not been well represented. As discussed by Burgan, et al. [8], the reasons for the difficulties in being able to effectively characterize shrublands and grasslands for fire applications are varied and many, but a large part of the problem revolves around the high degree of intra- and interannual variability in fuel characteristics in these areas, necessitating higher level understanding of the dynamics of these systems [8]. It is clear that more frequent observations will help to develop better understanding of the conditions that influence grassland and shrubland fuel characteristics and consequently wildland fire behavior and spread.

The Moderate Resolution Imaging Spectroradiometer (MODIS) provides great opportunities to monitor vegetation changes in shrubland/grassland ecosystems. Although MODIS has coarser spatial resolution (two bands at $250 \mathrm{~m}$ resolution in addition to other coarser resolution bands) than Landsat (multiple bands at $30 \mathrm{~m}$ resolution), it has daily monitoring capability and a suite of products available for use. These MODIS products have had atmospheric corrections and cloud screening applied [9], and the data can be used to monitor changes in near-real time. Although many studies have used MODIS products to monitor various vegetation dynamics such as the changes in vegetation phenology, biomass, and fuel moisture [10-14], only few of them have investigated the use of MODIS products for 
assessing fuel loads [15-17]. Live fuel is defined as the live vegetative biomass above the ground in which the seasonal moisture content cycle is controlled largely by internal physiological mechanisms, rather than by external weather influences [8]. Given the close correlations between live fuel loads and live vegetation biomass, it is reasonable that we can estimate the changes in live fuel load using MODIS products. Compared to LANDFIRE fuel data that lacks temporal resolution, MODIS offers the advantages of a harmonized, long-term, and spatially extensive record to observe dynamic living fuel loads. Recent advances in remote sensing applications and meta-analyses allow development of dynamic live fuel loads at broad spatial and temporal scales.

One challenge of using remote sensing data for fuel load studies is the estimation of the dynamics of dead fuel loads. Dead fuel loads include the dead leaves and branches on the ground or standing within the live vegetation and contribute significantly to fire behavior and hazards. No existing remote sensing products directly estimate these dead components. With certain information of ecological processes such as mortality, turnover, and decomposition, it should be possible to assess the changes in dead fuel loads separately from the changes in live fuel loads. Ecological models, which have been developed to describe these ecological processes, can be used with remote sensing observations to produce estimates of the dynamics of dead fuel loads.

In this study, we first used the weekly composited Normalized Difference Vegetation Index (NDVI) data from an "expedited" MODIS (eMODIS) that [18] processed to demonstrate the degree that aboveground live fuel loads change within and between years for a typical sagebrush-dominated shrubland/grassland ecosystem in the western United States. We also used the MODIS Net Primary Production (NPP) product to estimate the changes in live and dead fuel loads for multiple years. Finally, we simulated the fire behavior changes based on the estimates of live and dead fuel loads from MODIS NPP. Our goals include quantifying the range of intra- and interannual variability in the fuel loads of the shrubland/grassland ecosystem, and assessing how the variability in fuel loads affects fire spread simulations. In this study we will use the terms "fuel load" and "biomass" largely synonymously, with "fuel load" mostly in the discussion of fire models and fire risk, and "biomass" mostly in the discussion of mapping results and vegetation growth.

\section{Methods}

\subsection{Study Area}

The Owyhee Upland and adjacent Twin Falls region is located in the northern part of the Great Basin and covers $41,000 \mathrm{~km}^{2}$ in southwestern Idaho, northern Nevada, and southeastern Oregon (Figure 1). This area lies mostly within the Owyhee High Plateau as classified by the U.S. Department of Agriculture (USDA) Natural Resources Conservation Service [19]. Rangeland and irrigated cropland are the two major land uses in this area. Irrigated cropland is mainly located in the eastern part of the region. The rest of the area is dominated by rangeland covered with sagebrush steppe communities. According to the LANDFIRE classification, the region is $40 \%$ grasslands, $42 \%$ shrublands mixed with grass, and 9\% nonburnable (urban and agricultural area) land cover (Figure 2a).

The average annual precipitation in this region ranges from 180 to $205 \mathrm{~mm}$ with most of the precipitation in the fall, winter, and spring, and little precipitation in the summer [19]. The average annual temperature is 2 to $12{ }^{\circ} \mathrm{C}$ but monthly temperatures can be over $30^{\circ} \mathrm{C}$ in summer months. This region has had frequent fires from the previous several decades (Figure 1), as indicated by the Monitoring Trends in Burn Severity [20] data.

A large shrubland/grassland fire area within the Owyhee Basin, the Murphy fire region, was selected for the study of fuel dynamics, fire behavior, and fire spread (Figure 1). This fire event, named the Murphy Wildland Fire Complex, comprised a series of wildland fires ignited by lightning on July 16 and 17 and continued to expand until July 23, 2007. Fire spread was ultimately reduced by light rain and thunderstorms after July 23, but the fire was not fully contained until August 2 [21]. The total burned area was more than 260,000 hectares. Over $98 \%$ of the burned area was classified as 
shrubland/grassland fuel types (Figure 2b). The dominant fuel types were GR2 (low-load, dry-climate grass) and GS2 (moderate-load, dry-climate grass-shrub) [22]. Wyoming sagebrush with an understory of native grasses was the dominant vegetation community and only about $20 \%$ of the area burned was grassland [21]. From 1984 to 2000, several small fires occurred in this region but much of the area had no fire disturbances recorded from 2000 to 2007 [20].

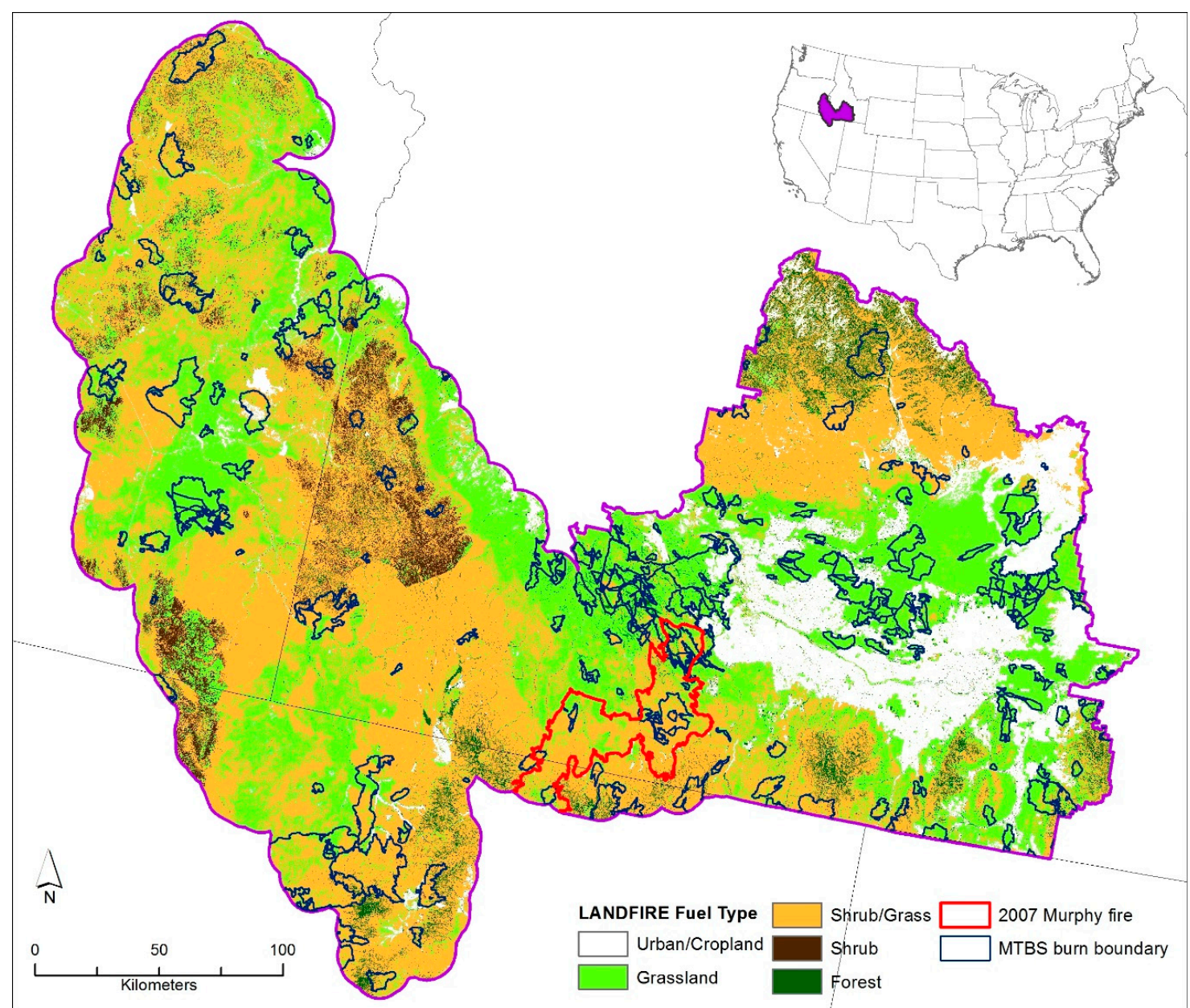

Figure 1. The LANDFIRE program fuel types in the Owyhee Uplands and Twin Falls regions (purple boundary), Monitoring Trends in Burn Severity (MTBS)-recorded fire history from 2001 to 2010 (blue boundaries), and the boundary of 2007 Murphy fire (red boundary).

Owyhee Uplands Region

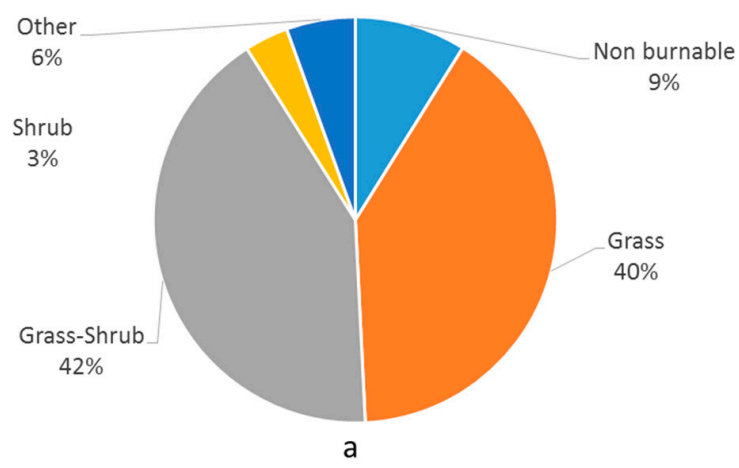

Murphy Fire Region

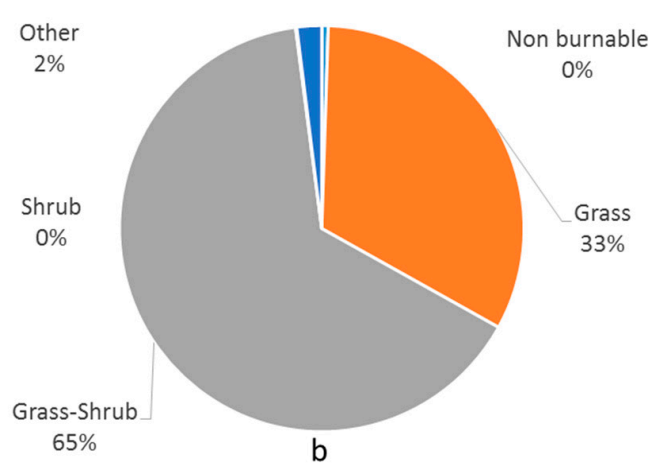

Figure 2. Percentage of area in LANDFIRE fuel types in the Owyhee region (a) and the Murphy fire region (b). 


\subsection{Fuel Dynamics Estimated from MODIS Products}

Intra- and interannual variability in live fuel conditions was analyzed using weekly eMODIS NDVI data in the Owyhee/Twin Falls region. eMODIS data [18] are weekly composited MODIS data for the conterminous United States generated at the U.S. Geological Survey (USGS) Earth Resources Observation and Science (EROS) Center with the primary purpose of facilitating MODIS data use. The pixel with the highest NDVI value in each week is used to generate the composite value for the weekly composite data. NDVI data are available from 2000 to the present at $250 \mathrm{~m}$ resolution and provide historical observations that enable time series analyses and comparison among selected time intervals. While eMODIS data are relatively spatially coarse, the temporal resolution of the data provides excellent information about weekly to monthly intra-annual vegetation status and conditions.

eMODIS NDVI data do not directly measure biomass (or fuel loads) and additional methods are required to translate spectral information into fuel loads, which are required for simulating fire behavior and spread. We developed an empirical model to convert NDVI values to aboveground live biomass using biomass information from the literature [23-25] and by assuming a log relationship between the NDVI and the live biomass [26]. We assumed that the higher NDVI values were associated with pixels that had live biomass levels at the upper end of the values reported in the literature, and that the lower NDVI values were close to zero biomass, and interpolated the values in between. We then generated the 2000 through 2011 weekly time series spatial products depicting live biomass for areas depicted as shrublands and grasslands in the LANDFIRE data. Dead biomass production was derived by subtracting the weekly live biomass datasets from the maximum live biomass that occurred in spring (highest level occurring in weeks 19 to 26). Near zero values indicated little change in live biomass levels from the maximum, implying low levels of dead biomass, whereas relatively high values indicated large changes from the live to dead biomass.

We also estimated the annual live and dead fuel loads from the MODIS NPP data in the Murphy fire region. NPP represents the amount of biomass that vegetation assimilates through photosynthesis $[27,28]$. NPP is also the difference between Gross Primary Production (GPP) and the Autotrophic Respiration (AR) [27,29]. GPP can be estimated from satellite-derived NDVI data and the Photosynthetically Active Radiation (PAR) with a conversion efficiency factor $\varepsilon$ :

$$
G P P=\varepsilon \times F P A R \times P A R \approx \varepsilon \times N D V I \times P A R
$$

FPAR is the fraction of PAR that is absorbed by vegetation. The conversion factor $\varepsilon$ is the light use efficiency (LUE) factor and its value is affected by biological and environmental factors [29,30]. In the MODIS NPP algorithm, $A R$ is estimated from the MODIS LAI/FPAR product and NPP is calculated annually as the difference between GPP and $A R$ [31,32].

We used the global MODIS NPP (MOD17A3) product provided by the Numerical Terradynamic Simulation Group (NTSG) located at the University of Montana [33]. The MODIS NPP product was generated at $1 \mathrm{~km}$ spatial resolution from 2000 to 2010 using the most recent version of the algorithm [32,34]. We resampled the LANDFIRE surface fuel map to $1 \mathrm{~km}$ resolution and used the resampled map as the mask for estimating the NPP for grass fuel type and the grass-shrub fuel type. We assumed a 100\% NPP allocation to grass (live herbaceous fuel) whereas for the grass-shrub fuel type, NPP allocations were $50 \%$ to grass and $50 \%$ to shrub (live woody fuel).

The amount of aboveground biomass is allocated by partitioning the overall NPP. We used the partition parameters from the Biome-BGC model to estimate the live fuel load changes from MODIS NPP. Biome-BGC, a process-based model developed for studying terrestrial ecosystem carbon cycling, has been widely used for ecosystem level studies [35-37].

First, we estimated the live fuel loads from MODIS NPP. The amount of annual live herbaceous fuel is estimated from the grass NPP as follows:

$$
\text { Livefuel herb }_{\text {h }}(t)=N P P_{\text {grass }}(t) \times \frac{1}{1+f_{\text {FRC:LC }}}
$$


The allocation parameter $f_{F R C: L C}$ is the ratio of new fine root carbon to new leaf carbon for grass. This formula assumed that all the previous year's live herbaceous fuel was transferred to the dead fuel load. The amount of live woody fuel is estimated based on the shrub NPP and the woody fuel load from the previous year:

$$
\text { Livefuel }_{\text {woody }}(t)=N P P_{\text {shrub }}(t) \times \frac{1+f_{S C: L C}}{1+f_{F R C: L C}+f_{S C: L C}}+\text { Livefuel }_{\text {woody }}(t-1)-\operatorname{litter}(t)_{\text {produce }}
$$

The allocation parameter $f_{F R C: L C}$ is the ratio of new fine root carbon to new leaf carbon allocation and the allocation parameter $f_{S C: L C}$ is the ratio of new stem carbon to new leaf carbon allocation for shrub biomes. Both Equations (1) and (2) are used to calculate the live herbaceous fuel load and live woody fuel load changes in the grass-shrub fuel type.

Second, we calculated the dead fuel load using the live fuel load information. The change of the dead fuel load is controlled by three major processes:

$$
\begin{gathered}
\operatorname{Deadfuel}(t)=\operatorname{litter}(t)_{\text {produce }}-\operatorname{litter}(t)_{\text {decomp }}-\operatorname{litter}(t)_{\text {removal }}+\operatorname{Deadfuel}(t-1) \\
\operatorname{litter}(t)_{\text {produce }}=\operatorname{Livefuel}(t-1) \times\left(f_{\text {turnover }}+f_{\text {mortality }}\right)
\end{gathered}
$$

where litter ${ }_{\text {produce }}$ is the production of litter from the live vegetation, litter decomp $_{\text {is }}$ the loss of litter through decomposition, and litter ${ }_{\text {removal }}$ is the removal of litter from the surface by disturbances

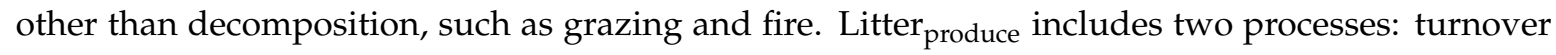
and mortality [37]. Deadfuel $(t-1)$ is the turnover portion of the live plant pools that are replaced each year. " $\mathrm{t}$ " is yearly steps. The typical turnover time of grass was set to $1.0 \mathrm{yr}^{-1}$, which means that all the aboveground live biomass will turn into litter in the next year. For shrubs, the live leaf biomass turnover time was estimated as the inverse of the leaf longevity time. We set the leaf turnover rate of shrub to $1.0 \mathrm{yr}^{-1}$ [38] and the woody turnover rate to $0.01 \mathrm{yr}^{-1}$ [39]. Mortality is the portion of the plant pool that is lost because of vegetation death. The whole plant mortality rate of grass was set to 0.4 and the mortality rate of shrub was set to a constant 0.02 [37]. To simplify the calculation, we assumed that the live biomass only changed to dead biomass at the end of the growing season and all the dead

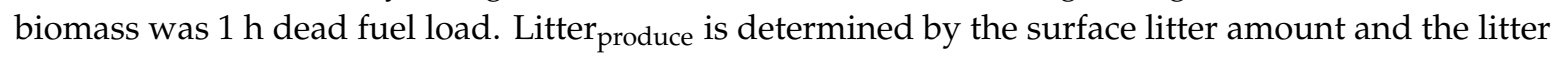
decomposition rate. The litter decomposition rate is impacted not only by the different components of the litter but also by environmental conditions such as soil temperature and moisture. We simplified the calculation by using a decay constant for all the litter pools. Generally, the mass loss of litter can be approximated by a simple model with an exponential decay function:

$$
\operatorname{litter}(t)=\operatorname{litter}(t-1) \times e^{-k t}
$$

Litter $(t-1)$ is the aboveground litter mass in the previous year, litter $(t)$ is the litter mass remaining at the current year without considering the new litter production and removal, $\mathrm{k}$ is the decay constant, and $t$ is time. We reviewed the literature and used the mean decay constant $\left(0.5 \mathrm{yr}^{-1}\right)$ of the litter

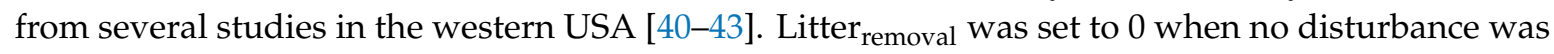
detected (fire, grazing, etc.). When there was a fire event, we assumed the fraction of litter removed by the fire to be $90 \%$ [44]. We ran the model in the Murphy fire region from 1984-2000 to simulate the initial litter condition for shrublands and grasslands. For this prerun period, we used the MODIS NPP 10-year average as NPP input and assumed there were no disturbances ( Litter $_{\text {removal }}=0$ ).

Last, we set the litter removal rate to 0 for the simulation period 2000-2007 because there was no disturbance detected (fire, grazing, etc.) for most of the area. The fire event in 2007 removed a large amount of surface fuel load, but we did not have field data to estimate the removal of biomass. Therefore, we assumed the live shrub fuel load and dead fuel load were reduced by $90 \%$ [44]. 


\subsection{Fire Behavior Simulation}

We used two methods to demonstrate how the temporal dynamic fuels layers influenced fire behavior and fire spread. First, we used the BehavePlus fire modeling [45] to calculate the fire behavior indices of National Fire Danger Rating System (NFDRS) [46-48], and we estimated variability in fire behavior under different fuel loads. Second, we used the Fire Area Simulator (FARSITE) [49] to simulate the fire spread behavior in the Murphy fire region. The general modeling approach was to simulate fire behavior and spread and determine levels of sensitivity to the different fuel loads as estimated from remotely sensed data.

For the BehavePlus simulation, we calculated two indices commonly used for fire management decisions in the NFDRS analysis: the Energy Release Component (ERC) and Flame Length (FL). We used fuel moisture values representing very dry conditions (3\% 1-h; 4\% 10-h; 5\% 100-h; 30\% live herbaceous; $60 \%$ live woody) and low wind speed ( $5 \mathrm{mph}$ ). From our fuel load estimates, we created a number of custom fire-behavior fuel models for shrublands and grasslands:
a. High: fuel parameters were set as the year with high live fuel load (2005)
b. Low: fuel parameters were set as the year with low live fuel load (2008)
c. Moderate: fuel parameters were set as the year of the Murphy fire (2007)
d. Default: fuel parameters were set as the default values from LANDFIRE

Each custom fuel model file included three parameters specifying live herbaceous, live woody fuel, and 1-h dead fuel loads, which varied year-to-year. The default fuel models included the low-load, dry climate grass (GR2) fuel and moderate load, dry climate grass-shrub (GS2) fuel models that fuel parameters were set as the default values from LANDFIRE. FARSITE is a PC-based application software program that is widely used by different agencies for wildland fire management (Finney 2004). For the FARSITE simulations, the spatial data of the fuel models and other surface parameters (elevation, topographic aspect, and slope) were downloaded from the LANDFIRE data portal and extracted for the Murphy fire region. LANDFIRE data have $30 \mathrm{~m}$ resolution and we resampled all the data to $1 \mathrm{~km}$ resolution to match our MODIS NPP-derived fuel load data.

All FARSITE simulations were performed from July 16-23, 2007, using the historical weather data for fire planning analysis from the North American Regional Reanalysis (NARR) dataset [50]. Daily temperature, relative humidity, wind direction, wind speed, and precipitation data were extracted from the NARR dataset and used in the simulation. The initial fuel moistures were calculated from the weather data in FARSITE. All the simulations used the fire initialization point (Lat $42.16^{\circ}$, Long $-115.32^{\circ}$ ) recorded in the MTBS database as the only ignition.

\section{Results}

\subsection{Fuel Dynamics Estimated from MODIS NDVI Products}

The shrublands/grasslands from the Owyhee Uplands region showed a high degree of interannual variability in vegetation greenness, as depicted by the NDVI profile (Figure 3). There was a slight but gradual increase in greenness throughout the 2000-2011 time periods. One of the high fire years (2005) had the highest NDVI values, and two of the other three high fire years had higher than average NDVI profiles those from the other years. Plots of NDVI time series in grasslands (not shown) showed the same general patterns, although the NDVI values tended to be higher than in shrublands.

Decided differences were noted between images depicting spatial patterns in live fuels for low versus high fire years (e.g., 2001 versus 2005; Figure 4). Greenness was highest in the spring, which is when live fuel loads should be the greatest. This is when rainfall is the most plentiful, and vegetation is actively growing throughout the region. Variability in greenness patterns in the imagery tended to be highest in the spring datasets. Meanwhile, the summer data depicted much lower levels of green vegetation throughout the region. Shrubland/grassland areas had lower levels of heterogeneity in greenness patterns in the summer than in the spring (Figure 4). These areas typically "brown-up" 
during the summer months as the rainfall diminishes. Areas with high greenness in the spring, and low greenness in the summer, have the greatest potential for burning.

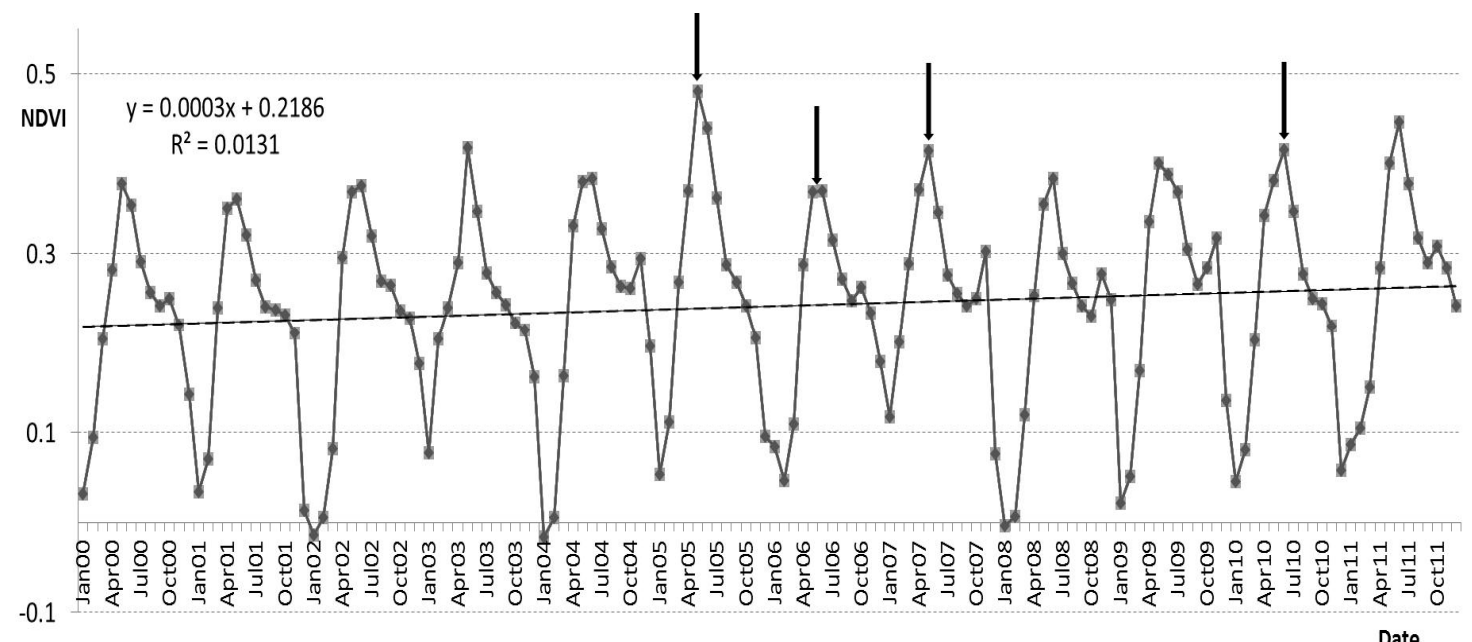

Figure 3. Seasonal Normalized Difference Vegetation Index (NDVI) profile for shrublands in the study area (aggregated from 3357 shrubland plots and field data). Arrows denote years that had large burned area relative to other years. The trend line indicates that greenness in these shrublands trended upward over the time frame.
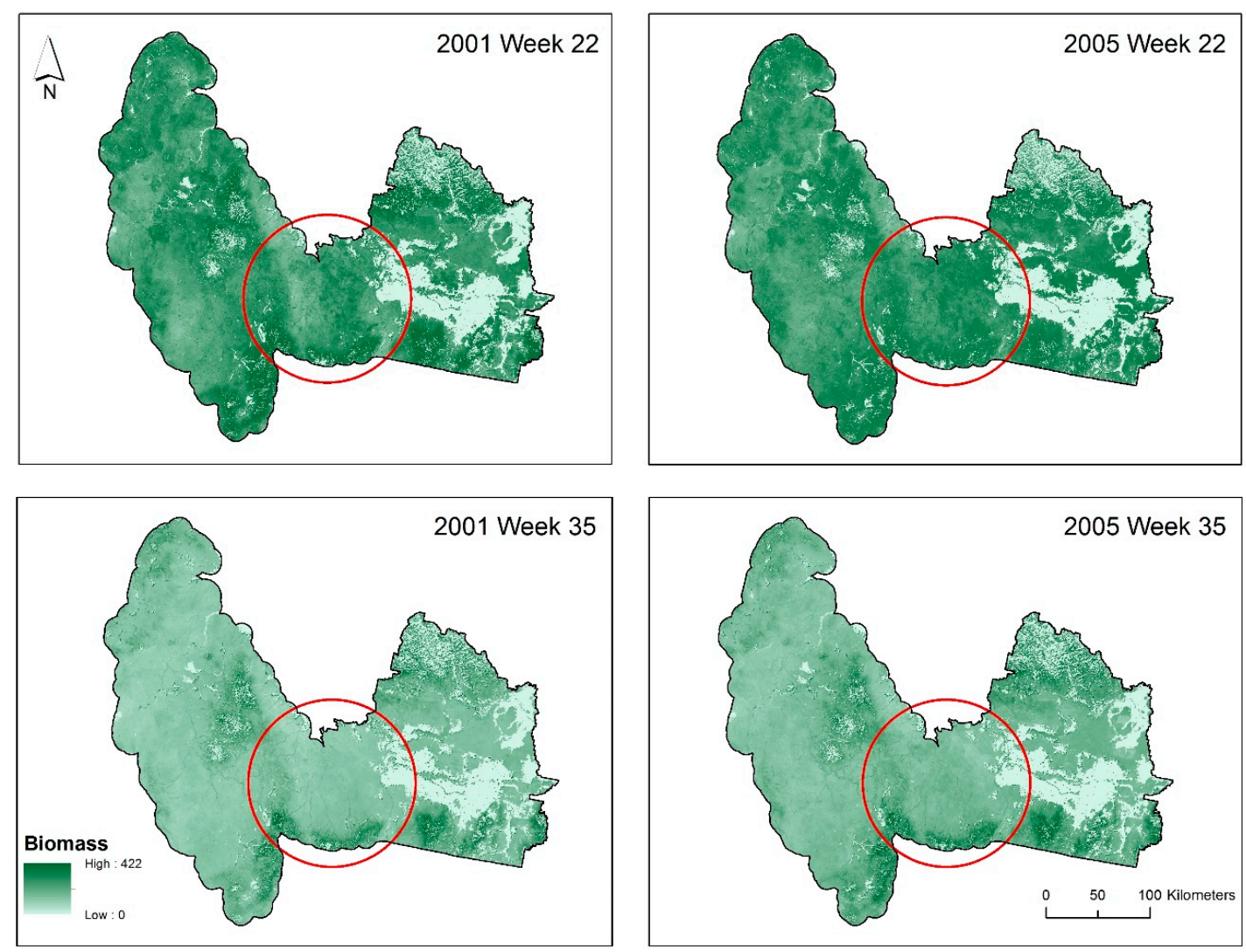

Figure 4. Image comparisons showing live fuels for a low fire year (2001) versus a high fire year (2005) for spring (top) and summer (bottom). The darker tone of the 2005 spring live fuel image indicates higher biomass for that year. Differences between spring and summer images indicate the loss of green biomass as a function of summer heat and seasonal dryness. The red circle indicates an area where fire occurrence was especially frequent from 2000 to 2011, and includes the Murphy Fire. 
Comparison between shrubland sites that burned at least once between 1984 and the present, and those that did not, indicated spectral differences between the two groups (Figure 5). Those sites that burned at least once tended to have higher live biomass levels in spring and higher dead biomass levels in summer than those sites that did not burn during the time frame. Figure 5 shows dead biomass for one burned site versus the mean dead biomass for sites that have not recently burned. We noticed that the levels of dead biomass are often, but not always, particularly high during the year that the site burned.

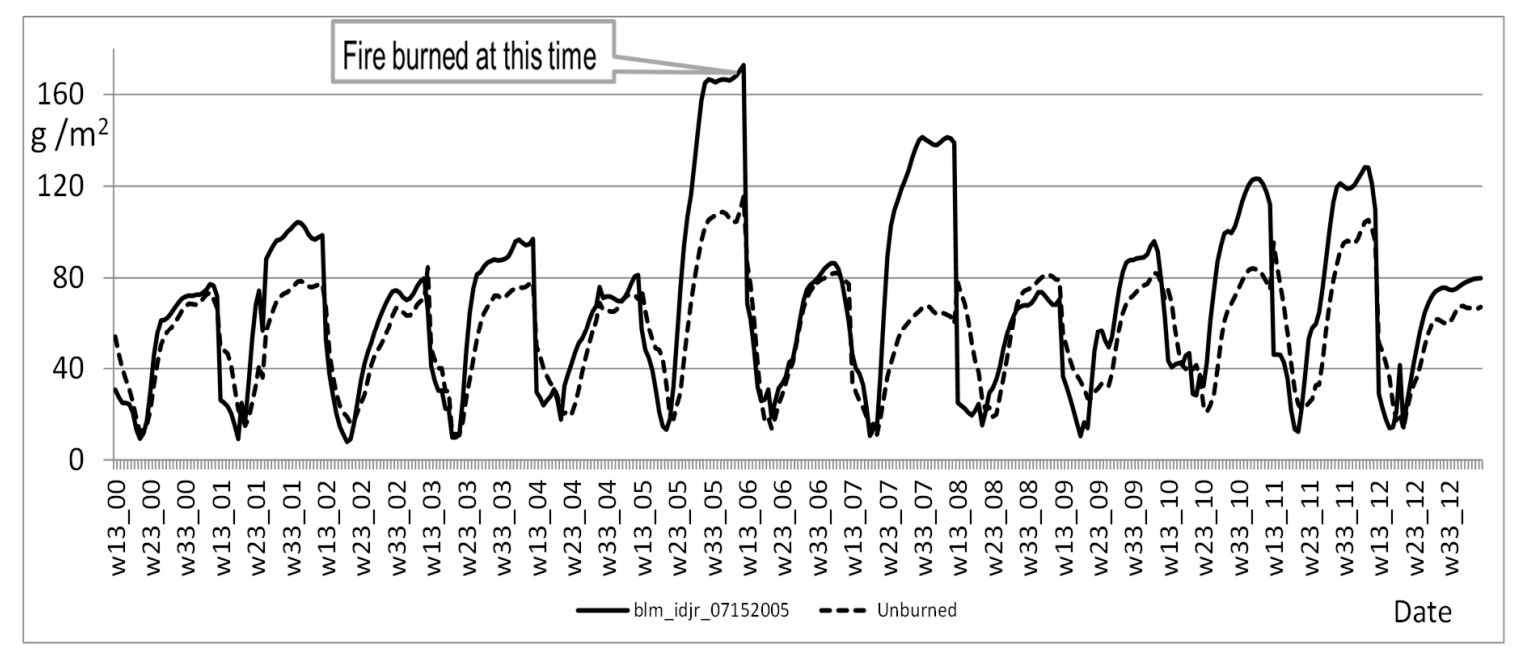

Figure 5. Dead biomass for a single burn area (burned on July 15, 2005; solid line) versus mean biomass for sites that did not burn at any point during the 1984-2010 time frame (dashed line). Note that the burn area typically had higher biomass than the sites that did not burn throughout the entire time frame, with especially high values for the year that the site burned (as well as in 2007, when the site did not burn). The time axis represents the week of the year that biomass is estimated (e.g., w13_00 is the 13th week in 2000).

\subsection{Fuel Dynamics Estimated from MODIS NPP}

The annual precipitation and the annual MODIS NPP for the Murphy fire region are shown in Figure 6a. MODIS NPP showed a slight decrease from 2000 to 2002 as the annual precipitation decreased, and increased to a peak value in 2005 when annual precipitation was highest. The similarities between NPP changes and annual precipitation illustrate the degree that precipitation impacts vegetation production in these shrub- and grass-dominated systems.

The annual changes in the estimated live and dead fuel loads are presented in Figure $6 b, c$ for the Murphy fire region. For grasslands, the estimated mean and standard deviation of the live herbaceous fuel load was $2.65 \pm 0.39$ metric ton per hectare (ton ha ${ }^{-1}$ ) during the 10-year period, with the highest value in 2005 and the lowest value in 2008 (Figure 6b). The highest live fuel load (3.28 metric ton $\mathrm{ha}^{-1}$ in 2005) was about $56 \%$ higher than the lowest fuel load (2.09 metric ton ha in 2008). After 2000, the live fuel load decreased to the lowest value in 2002 and then increased to the highest value in 2005. The mean annual $1 \mathrm{~h}$ dead fuel load (3.34 \pm 1.48 metric ton ha $\left.^{-1}\right)$ was about $20 \%$ higher than the live fuel load $\left(2.65 \pm 0.39\right.$ metric ton $\left.\mathrm{ha}^{-1}\right)$ from 2000 to 2009 . The dead fuel changes showed a time lag compared with the live fuel load changes. The lowest dead fuel load value was in 2004 and the highest value was in 2007. Both of these were about one or two years later than the live fuel load lowest and highest values. This time lag is expected because the live fuel load accumulated during the growing season is used to calculate the dead fuel load production in the next year. Thus, the changes in live fuel load in one year only alter the input to the dead fuel load in the next year. Our results also showed clear impact of the fire event on live and dead fuel loads. After the fire event in 2007, both live and dead fuel loads showed the lowest values in 2008. The live herbaceous fuel showed much faster recovery than dead fuel after two years. 


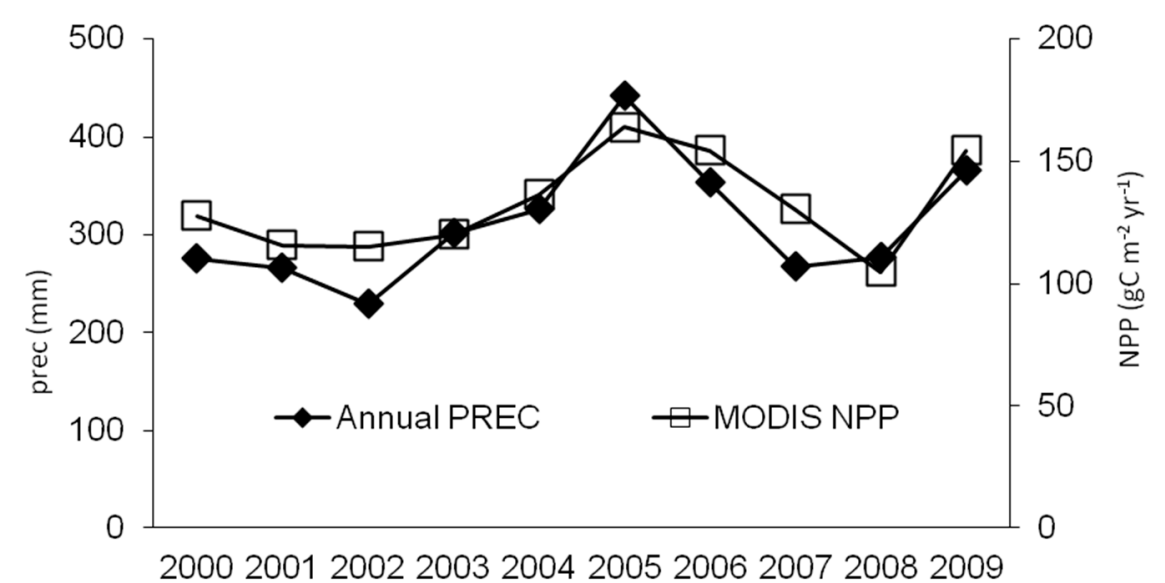

a
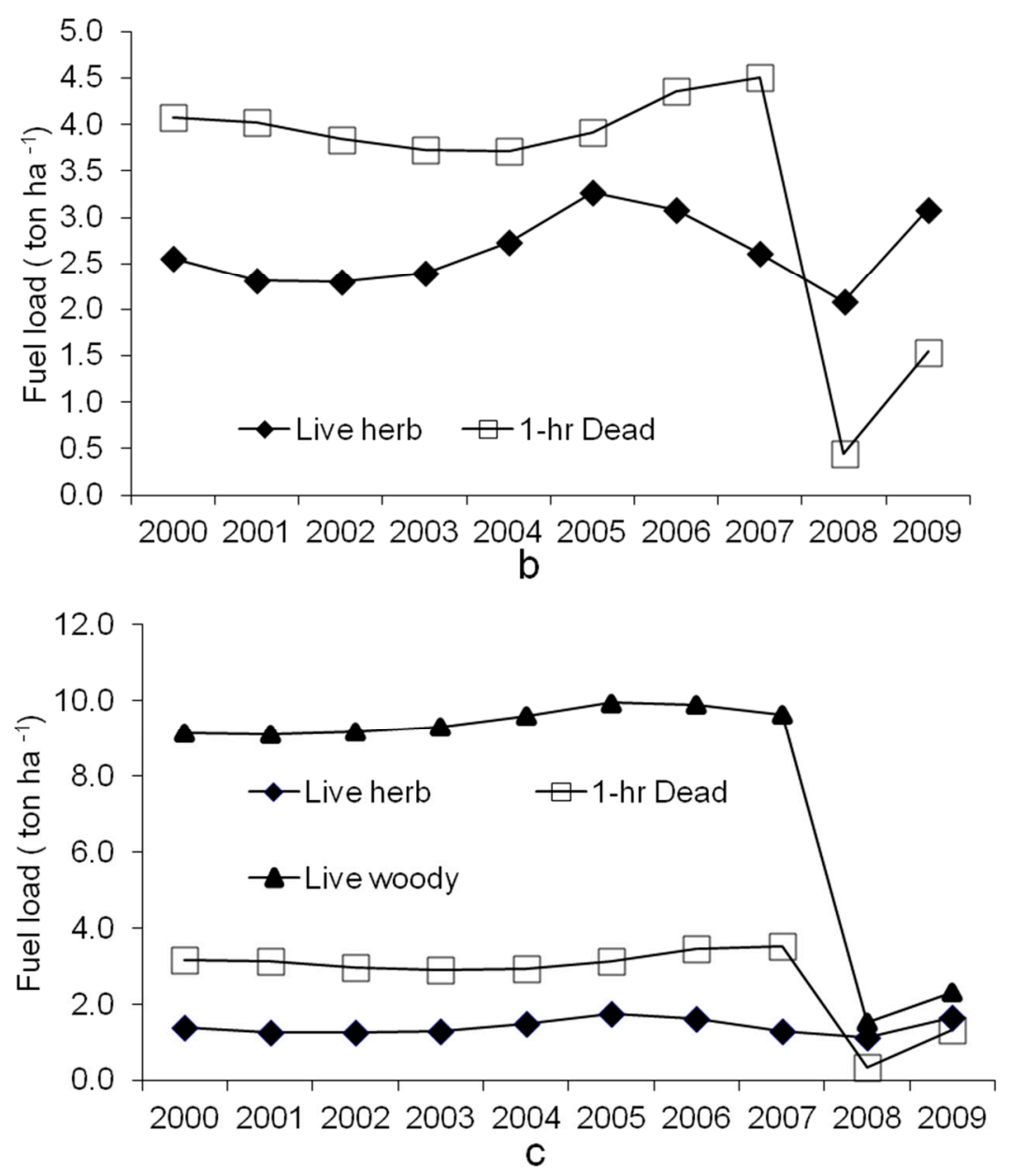

Figure 6. Climate and vegetation condition changes in the Murphy fire region from 2000 to 2009: (a) Moderate Resolution Imaging Spectroradiometer (MODIS) net primary production and annual precipitation, (b) live herbaceous fuel and $1 \mathrm{~h}$ dead fuel changes for fuel type GR2 (low-load, dry-climate grass), (c) live fuel, live woody, and $1 \mathrm{~h}$ dead fuel changes for fuel type GS2 (moderate-load, dry-climate grass-shrub).

For shrublands, the estimated total fuel load was much higher than the total fuel load for grasslands even though they have similar productivities. The high amount of live woody fuel load was the main cause of this difference. The live woody fuel load comprised about $66 \%$ of the total fuel load and was much higher $\left(7.97 \pm 3.20\right.$ ton ha $\left.{ }^{-1}\right)$ than the live herbaceous fuel load $\left(1.42 \pm 0.20\right.$ ton ha $\left.^{-1}\right)$ and the $1 \mathrm{~h}$ 
dead fuel load $\left(2.64 \pm 1.14\right.$ ton $\left.\mathrm{ha}^{-1}\right)$ during the 10-year period (Figure $6 \mathrm{c}$ ). The fuel dynamics for shrubland kept increasing and showed less interannual variation than the fuel dynamics for grasslands. The fire event in 2007 removed most of the fuel load and the total fuel load was reduced by $80 \%$ (2.09 ton ha ${ }^{-1}$ in 2008) compared with the previous year (14.46 ton ha ${ }^{-1}$ in 2007).

\subsection{Fire Behavior Simulation}

The input parameters used for the BehavePlus simulation and the simulated NFDRS Energy Release Component (ERC) and Flame Length (FL) are listed in Table 1. The ERC and FL values varied markedly among years, fuel loads, and fuel types, and results were consistent with our expectations. For instance, ERC and FL were greater in years with high to moderate fuel loads (2005 and 2007) than years with low fuel loads (2008) in both grass and shrub vegetation types (Table 1). Meanwhile, ERC values were higher in shrublands than in grasslands, while FL values were higher in grasslands than in shrublands. Depending on the fuel load, ERC and FL values in the high and moderate fuel load years were often very different from the values in the low fuel load years and the LANDFIRE (default) fuel loads.

Table 1. Fuel load values and simulated fire behavior indices for different fuel load scenarios.

\begin{tabular}{ccccccc}
\hline \multirow{2}{*}{$\begin{array}{c}\text { Fuel } \\
\text { Type }\end{array}$} & Fuel LOAD & \multicolumn{2}{c}{ Fuel loads (ton ha-1) } & & \\
\cline { 3 - 5 } & & $\begin{array}{c}\text { Live } \\
\text { Herbaceous }\end{array}$ & $\begin{array}{c}\text { Live } \\
\text { Woody }\end{array}$ & $\begin{array}{c}\text { 1-Hour } \\
\text { Dead }\end{array}$ & $\begin{array}{c}\text { ERC } \\
\text { (1KJ } \\
\mathbf{~ m}^{\mathbf{2}} \text { ) }\end{array}$ & FL $^{\mathbf{2}(\mathbf{m})}$ \\
\hline Grass & High (2005) & 3.27 & 0 & 3.92 & 10425 & 3.41 \\
Grass & Moderate (2007) & 2.6 & 0 & 4.5 & 10209 & 3.38 \\
Grass & Low (2008) & 2.08 & 0 & 0.45 & 3043 & 1.95 \\
Grass & Default (GR2) & 2.24 & 0 & 0.22 & 2953 & 1.92 \\
Shrub & High (2005) & 1.75 & 9.95 & 3.12 & 20043 & 3.23 \\
Shrub & Moderate (2007) & 1.3 & 9.64 & 3.52 & 19544 & 3.23 \\
Shrub & Low (2008) & 1.14 & 1.52 & 0.36 & 3770 & 1.58 \\
Shrub & Default (GS2) & 1.34 & 2.24 & 1.12 & 6348 & 2.16 \\
\hline
\end{tabular}

1. ERC: Energy release component. 2. FL: Flame length.

For the FARSITE assessments, we simulated the area burned with high (2005), moderate (2007), low (2008), and default fuel loads (Table 2). None of the simulations resulted in a total burned area that was similar to the actual area burned by the Murphy Wildland Fire Complex (260,000 ha). One important reason for the differences between the model simulation and the real fire event is that the Murphy Wildland Fire Complex comprised a series of fires with multiple ignition points rather than the single ignition point used in the simulation [21]. In spite of that, we found that the simulated burned area was more sensitive to the differences in $1 \mathrm{~h}$ dead fuel load than differences in the live herbaceous and live woody fuel loads. The live herbaceous and live woody fuel loads had higher values in 2005 than in 2007, but the simulated burned area was about 4\% lower in 2005 than in 2007. The higher burned area in 2007 was probably a result of the larger $1 \mathrm{~h}$ dead fuel loads in 2007 . We found that FARSITE simulated less burned area when the live woody fuel load increased in shrublands. All three scenarios have higher live woody fuel loads than the LANDFIRE fuel models yet the simulated burned areas were less than the burned area simulated with the LANDFIRE fuel model parameters. Our results indicated that increases in dead fuel loads may result in greater fire hazards than increases in live fuel loads. 
Table 2. Burned area simulated by Fire Area Simulator (FARSITE) for fuel loads in different years.

\begin{tabular}{cc}
\hline Live Fuel Load & Area Burned (ha) \\
\hline High (2005) & 33,998 \\
Moderate (2007) & 35,386 \\
Low (2008) & 32,937 \\
Default & 48,593 \\
\hline
\end{tabular}

\section{Discussion}

\subsection{Climate Impacts on Shrubland/Grassland Fuel Load Changes}

Climate condition is the most important driver of fuel load accumulation on shrubland/grassland ecosystems. The most recent report on climate change indicates that North America may have warmer winter and spring temperatures and more spring precipitation [51]. Higher spring precipitation tends to increase the live vegetation production for the shrubland/grassland ecosystems in our study area, which results in higher fuel loads in the summer than years with a dry spring. Higher fuel loads, as predicted by fire model simulations, resulted in larger energy release component and flame length values, and also greater burn area. Thus, it is likely that climate change will bring more extreme fires in the shrubland/grassland region by increasing the fuel load.

It is very important to be able to assess vegetation condition and status during the spring time frame for fire applications. Biomass production is highest in spring, and high levels of spring biomass set the stage for high levels of burnable fuels later in the year. The eMODIS NDVI data can depict current greenness and brownness conditions but generally fall short at capturing some important ecophysiological processes such as decomposition, at least without additional information. There is also a notable time lag effect between climate and the dead fuel changes. If not removed by grazing or fire, much of the live herb fuel load from one growing season will be converted into dead fuel load toward the end of growing season and carry over to the next year. Thus, a series of wet years followed by a dry year can markedly increase dead fuel loads and thus increase the potential of extreme fires.

Meanwhile, climate conditions also impact the litter decomposition process that controls the dead fuel changes. This process tends to be difficult to measure solely using remotely sensed data, and we see a clear role for integrating Biome-BGC results with analyses of satellite-based data. Modeling with Biome-BGC and other similar process-based models can provide useful information of dead fuel load dynamics not readily obtainable through satellite remote sensing.

\subsection{Fire History Impacts on Shrubland/Grassland Fuel Load}

Fire history is an important factor affecting surface fuel loads. Fuel availability in shrublands will be largely dependent on the time since fire. A mature shrubland community that burns will have more extreme fire behavior (as indicated by higher ERC and FL in our results) than a younger shrubland community under the same meteorological conditions. In this study, the live woody and $1 \mathrm{~h}$ dead fuel loads were driven not only by annual NPP but also by fuel load conditions during the previous years. This means that the surface fuel load will increase as the shrubland ages in the absence of disturbance. This agrees with previous field studies on shrublands. A study on shrublands with different stand ages found a three-year-old shrubland had significantly less fuel load (1228 $\mathrm{g} \mathrm{m}^{-2}$ in biomass) compared with 9- and 12-year-old shrublands (3817 and $4426 \mathrm{~g} \mathrm{~m}^{-2}$ in biomass) [52]. A study on mountain sagebrush in Wyoming also found that litter layer increased rapidly from $52 \mathrm{~g} \mathrm{C} \mathrm{m}^{-2}$ for a recent burn area (two years after fire) to $436 \mathrm{~g} \mathrm{C} \mathrm{m}^{-2}$ at an established sagebrush site (six years after fire) [23]. Shaw and Harte [42] studied the decomposition rate on different species in the Rocky Mountain region and found the mean decay constant of shrub litter was about $28 \%$ of the decay constant of forb litter. Thus, more litter will accumulate on shrublands than grasslands.

Shrublands typically recover more slowly than grasslands after the fire. For instance, several postfire studies found that Wyoming Sagebrush recovered very slowly after fire [53,54]. More 
information will be needed to accurately partition the vegetation production between shrublands and grasslands to assess the fuel load changes on shrubland/grassland ecosystems.

\subsection{Using MODIS Products in Fuel Studies}

Our approach showed that MODIS products can be very effective for estimating surface fuel load changes in grasslands and shrublands, and for portraying the actual fuel changes that take place within and between years. Thus, there is much potential for using MODIS to provide more accurate and detailed assessments of fuel load in these grass and shrub areas than the static fuel load estimates provided by the existing LANDFIRE products.

We believe that we can greatly improve upon the current approach. First, we foresee being able to improve upon the spatial resolution of the NDVI data used. While we used 250-m resolution MODIS data in this analysis, the spatial scale of these datasets could be refined using the spatial and temporal adaptive reflectance fusion model (STARFM) [55,56]. This model enables melding of high-temporal-resolution MODIS data with high-spatial-resolution Landsat data (30 m). This model has been applied successfully in numerous studies $[55,57,58]$. The STARFM-type modeling would enable generation of Landsat-like spatial data while retaining the temporal qualities of MODIS in the shruband grass-dominated systems that we are investigating. We envision developing Landsat-like NDVI data for the spring time frame annually using STARFM. While we typically have ample numbers of high quality MODIS datasets during the spring season, only a limited number of Landsat datasets are available at this time due to cloud cover and the relatively infrequent revisit cycle of Landsat (16 days). The merging of MODIS and Landsat data would provide the fire applications community with high spatial resolution NDVI and biomass data during the critical high-growth phase in these shrub and grasslands when acquisitions of high-resolution Landsat data are rare.

Second, the MODIS NPP is a global product and its generation includes biome type information, daily meteorological data, and the FPAR/LAI information at global level. This brings some uncertainties for regional studies. As an example, if we are interested in deriving an accurate NPP product for the western United States' shrublands and grasslands, we may find it beneficial to use regional information from the western United States such as the National Land Cover Database (NLCD) [59]. Being Landsat-based, the NLCD has higher spatial resolution and represents land cover in United States with more precision and accuracy than the MODIS land cover product. Integrating NLCD information into the NPP calculation will be an option for future improvement. We also believe that we can improve the Biome-BGC model so that it better captures the live and dead fuel load in the region. The uncertainty of the model parameters can be reduced by calibrating the parameters with local observations of the vegetation characteristics, such as the aboveground live biomass and litter biomass.

The approach presented in this study used information from general studies of the shrubland/grassland ecosystem, and it is acknowledged that the results have not been validated with field data. More extensive experimentation using accurate field information at the regional and local scale is required to derive a solid predictive model for fire spread prediction in shrubland/grassland ecosystems in the western USA. As shown in this study, incorporating dynamic fuel information can greatly alter the fire model predictions. Such efforts will need to be considered by scientists and decision makers who use these fire models. With the integration of observations from existing Earth observation products, such as MODIS products, we can greatly enhance the fire model performance to support fire risk assessment and planning in large regions.

\section{Summary}

We used the NDVI and NPP products from the MODIS sensors to estimate the fuel loads on a typical shrubland/grassland ecosystem in the western USA. Fuel loads on shrublands and grasslands were characterized by large intra- and interannual variability. Climate and disturbance history are the two major factors affecting this variability in vegetation conditions, which in turn impact fuel 
loads. Our study demonstrated that the variability in fuel loads can be effectively quantified using high-temporal-resolution MODIS products.

We also simulated the fire behavior and spread with the dynamic fuel loads. Our simulation results indicated that employing the newly derived biomass information into fire spread models not only alters the values of commonly used fire behavior indices but also changes the simulated amount of area burned. These findings suggested that accurately predicting fire behavior and spread will require detailed information on the fuel loads dynamics, which currently is not provided by existing static fuel loads information. Future work will focus on improving the fuel loads dynamics information using better spatial resolution data and more validation information, as well as integrating the information into fire models for various fire applications.

Author Contributions: Z.L., J.E.V., and H.S., and T.J.H. conceptualized the research; Z.L., H.S., J.E.V., T.J.H., and B.P. wrote the paper; Z.L., H.S., and T.J.H. conducted data analysis and designed the graphics; All authors have read and agreed to the published version of the manuscript.

Funding: This research received no external funding.

Acknowledgments: The funding for this research was provided by the National Aeronautics and Space Administration (NASA) Applied Science Program (A-35 Wildland Fires). Part of the funding for this research was provided by the LANDFIRE Program and by the U.S. Geological Survey (USGS) Climate and Land Use Mission Area through the National Assessment of Ecosystem Carbon Sequestration and Greenhouse Gas Fluxes (LandCarbon) project. Hua Shi's the work was performed under USGS contract 613PC00028. Any use of trade, firm, or product names is for descriptive purpose only and does not imply endorsement by the U.S. Government.

Conflicts of Interest: The authors declare no conflict of interest. The funders had no role in the design of the study; in the collection, analyses, or interpretation of data; in the writing of the manuscript, or in the decision to publish the results.

\section{References}

1. Stephens, S.L.; Ruth, L.W. Federal forest-fire policy in the United States. Ecol. Appl. 2005, 15, 532-542. [CrossRef]

2. Westerling, A.L.; Hidalgo, H.G.; Cayan, D.R.; Swetnam, T.W. Warming and earlier spring increase western U.S. Forest wildfire activity. Science 2006, 313, 940-943. [CrossRef] [PubMed]

3. Eidenshink, J.; Schwind, B.; Brewer, K.; Zhu, Z.-L.; Quayle, B.; Howard, S. A project for monitoring trends in burn severity. Fire Ecol. 2007, 3, 3-21. [CrossRef]

4. Program, J.F.S. Joint Fire Science Program. Available online: https://www.firescience.gov/ (accessed on 1 March 2017).

5. Rollins, M.G. L: A nationally consistent vegetation, wildland fire, and fuel assessment. Inter. J. Wildland Fire 2009, 18, 235-249. [CrossRef]

6. LANDFIRE. LANDFIRE Program. Available online: https://www.landfire.gov/ (accessed on 26 April 2017).

7. Vogelmann, J.E.; Howard, S.; Rollins, M.G.; Kost, J.R.; Tolk, B.; Short, K.; Chen, X.; Pabst, K.; Huang, C. Monitoring landscape change for landfire using multi-temporal satellite imagery and ancillary data. IEEE J. Sel. Top. Appl. Earth Obs. Remote Sens. 2011, 4, 252-264. [CrossRef]

8. Burgan, R.E.; Klaver, R.W.; Klarer, J.M. Fuel models and fire potential from satellite and surface observations. Inter. J. Wildland Fire 1998, 8, 159-170. [CrossRef]

9. Justice, C.O.; Townshend, J.R.G.; Vermote, E.F.; Masuoka, E.; Wolfe, R.E.; Saleous, N.; Roy, D.P.; Morisette, J.T. An overview of MODIS land data processing and product status. Remote Sens. Environ. 2002, 83, 3-15. [CrossRef]

10. Qi, Y.; Dennison, P.E.; Spencer, J.; Riaño, D. Monitoring live fuel moisture using soil moisture and remote sensing proxies. Fire Ecol. 2012, 8, 71-87. [CrossRef]

11. Reeves, M.C.; Zhao, M.; Running, S.W. Applying improved estimates of MODIS productivity to characterize grassland vegetation dynamics. Rangel. Ecol. Manag. 2006, 59, 1-10. [CrossRef]

12. Yebra, M.; Chuvieco, E.; Riaño, D. Estimation of live fuel moisture content from MODIS images for fire risk assessment. Agric. Forest Meteorol. 2008, 148, 523-536. [CrossRef] 
13. Yebra, M.; Dennison, P.E.; Chuvieco, E.; Riaño, D.; Zylstra, P.; Hunt, E.R.; Danson, F.M.; Qi, Y.; Jurdao, S. A global review of remote sensing of live fuel moisture content for fire danger assessment: Moving towards operational products. Remote Sens. Environ. 2013, 136, 455-468. [CrossRef]

14. Zhang, X.; Friedl, M.A.; Schaaf, C.B.; Strahler, A.H.; Hodges, J.C.F.; Gao, F.; Reed, B.C.; Huete, A. Monitoring vegetation phenology using MODIS. Remote Sens. Environ. 2003, 84, 471-475. [CrossRef]

15. Roberts, G.; Wooster, M.J.; Xu, W.; He, J. Fire activity and fuel consumption dynamics in sub-saharan Africa. Remote Sens. 2018, 10, 1591. [CrossRef]

16. Bajocco, S.; Dragozi, E.; Gitas, I.; Smiraglia, D.; Salvati, L.; Ricotta, C. Mapping fuels through vegetation phenology: The role of coarse-resolution satellite time-series. PLOS ONE 2015, 10, e0119811. [CrossRef] [PubMed]

17. Duff, T.J.; Keane, R.E.; Penman, T.D.; Tolhurst, K.G. Revisiting Wildland Fire Fuel Quantification Methods: The Challenge of Understanding a Dynamic, Biotic Entity. Forests 2017, 8, 351. [CrossRef]

18. Brown, J.F.; Howard, D.M.; Wylie, B.K.; Friesz, A.M.; Ji, L.; Gacke, C. Application-ready expedited modis data for operational land surface monitoring of vegetation condition. Remote Sens. 2015, 7, 16226-16240. [CrossRef]

19. USDA. Major Land Resource Regions Custom Report (USDA Agriculture Handbook 296). Available online: https://www.nrcs.usda.gov/wps/portal/nrcs/main/soils/survey/ (accessed on 22 October 2017).

20. MTBS. Monitoring Trends in Burn Severity. Available online: https://www.mtbs.gov/ (accessed on 1 August 2017).

21. Launchbaugh, K.; Brammer, B.; Brooks, M.; Bunting, S.; Clark, P.; Davison, J.; Fleming, M.; Kay, R.; Pellant, M.; Pyke, D.; et al. Interactions among Livestock Grazing, Vegetation Type, and Fire Behavior in the Murphy Wildland Fire Complex in Idaho and Nevada; U.S. Geological Survey: Fort Collins, CO, USA, 2008.

22. Scott, J.; Burgan, R.; Robert, E. Standard Fire Behavior Fuel Models: A Comprehensive Set for Use with Rothermel's Surface Fire Spread Model; U.S. Department of Agriculture, Forest Service, Rocky Mountain Research Station: Fort Collins, CO, USA, 2005.

23. Cleary, M.B.; Pendall, E.; Ewers, B.E. Aboveground and belowground carbon pools after fire in mountain big sagebrush steppe. Rangel. Ecol. Manag. 2010, 63, 187-196. [CrossRef]

24. Davies, K.W.; Bates, J.D.; Miller, R.F. Short-term effects of burning Wyoming big sagebrush steppe in southeast Oregon. Rangel. Ecol. Manag. 2007, 60, 515-522. [CrossRef]

25. Wright, C.; Prichard, S. Biomass Consumption during Prescribed Fires in Big Sagebrush Ecosystems; U.S. Department of Agriculture, Forest Service: Washington, DC, USA, 2006; pp. 489-500.

26. Gamon, J.A.; Field, C.B.; Goulden, M.L.; Griffin, K.L.; Hartley, A.E.; Joel, G.; Penuelas, J.; Valentini, R. Relationships between NDVI, canopy structure, and photosynthesis in three Californian vegetation types. Ecol. Appl. 1995, 5, 28-41. [CrossRef]

27. Chapin III, F.S.; Woodwell, G.M.; Randerson, J.T.; Rastetter, E.B.; Lovett, G.M.; Baldocchi, D.D.; Clark, D.A.; Harmon, M.E.; Schimel, D.S.; Valentini, R.; et al. Reconciling carbon-cycle concepts, terminology, and methods. Ecosyst. 2006, 9, 1041-1050. [CrossRef]

28. Scurlock, J.M.O.; Johnson, K.; Olson, R.J. Estimating net primary productivity from grassland biomass dynamics measurements. Glob. Change Biol. 2002, 8, 736-753. [CrossRef]

29. Running, S.W.; Nemani, R.R.; Heinsch, F.A.; Zhao, M.; Reeves, M.; Hashimoto, H. A continuous satellite-derived measure of global terrestrial primary production. BioSci. 2004, 54, 547-560. [CrossRef]

30. Prince, S.D.; Goward, S.N. Global primary production: A remote sensing approach. J. Biogeogr. 1995, 22, 815-835. [CrossRef]

31. Heinsch, F.; Reeves, M.; Votava, P.; Kang, S.; Milesi, C.; Zhao, M.; Glassy, J.; Jolly, W.; Loehman, R.; Bowker, C.; et al. User's Guide on GPP and NPP (mod17a2/a3) Products NASA MODIS Land Algorithm. Version 2.0; University of Montana: Missoula, MT, USA, 2003.

32. Zhao, M.; Heinsch, F.A.; Nemani, R.R.; Running, S.W. Improvements of the MODIS terrestrial gross and net primary production global data set. Remote Sens. Environ. 2005, 95, 164-176. [CrossRef]

33. NTSG. Numerical Terradynamic Simulation Group (NTSG). Available online: ftp://ftp.ntsg.umt.edu/pub/ MODIS/NTSG_Products/ (accessed on 1 August 2013).

34. Zhao, M.; Running, S.W. Drought-induced reduction in global terrestrial net primary production from 2000 through 2009. Science 2011, 334, 1496. [CrossRef] 
35. Running, S.W.; Coughlan, J.C. A general model of forest ecosystem processes for regional applications i. Hydrologic balance, canopy gas exchange and primary production processes. Ecol. Model. 1988, 42, 125-154. [CrossRef]

36. Thornton, P.E.; Law, B.E.; Gholz, H.L.; Clark, K.L.; Falge, E.; Ellsworth, D.S.; Goldstein, A.H.; Monson, R.K.; Hollinger, D.; Falk, M.; et al. Modeling and measuring the effects of disturbance history and climate on carbon and water budgets in evergreen needleleaf forests. Agric. Forest Meteorol. 2002, 113, 185-222. [CrossRef]

37. White, M.; Thornton, P.; Running, S.; Nemani, R. Parameterization and sensitivity analysis of the biome-BGC terrestrial ecosystem model: Net primary production controls. Earth Interact. 2000, 4, 1-85. [CrossRef]

38. Miller, R.F.; Schultz, L.M. Development and longevity of ephemeral and perennial leaves on Artemisia tridentata Nutt. ssp. wyomingensis. Great Basin Nat. 1987, 47, 227-230.

39. Perfors, T.; Harte, J.; Alter, S.E. Enhanced growth of sagebrush (Artemisia tridentata) in response to manipulated ecosystem warming. Glob. Change Biol. 2003, 9, 736-742. [CrossRef]

40. Kemp, P.R.; Reynolds, J.F.; Virginia, R.A.; Whitford, W.G. Decomposition of leaf and root litter of Chihuahuan desert shrubs: Effects of three years of summer drought. J. Arid Environ. 2003, 53, 21-39. [CrossRef]

41. Knorr, M.; Frey, S.D.; Curtis, P.S. Nitrogen additions and litter decomposition: A meta-analysis. Ecology 2005, 86, 3252-3257. [CrossRef]

42. Shaw, M.R.; Harte, J. Control of litter decomposition in a subalpine meadow-sagebrush steppe ecotone under climate change. Ecol. Appl. 2001, 11, 1206-1223.

43. Throop, H.L.; Archer, S.R. Interrelationships among shrub encroachment, land management, and litter decomposition in a semidesert grassland. Ecol. Appl. 2007, 17, 1809-1823. [CrossRef] [PubMed]

44. Zhu, Z.; Bergamaschi, B.; Bernknopf, R.; Clow, D.; Dye, D.; Faulkner, S.; Forney, W.; Gleason, R.; Hawbaker, T.; Liu, J.; et al. A Method for Assessing Carbon Stocks, Carbon Sequestration, and Greenhouse-Gas Fluxes in Ecosystems of the United States under Present Conditions and Future Scenarios; U.S. Geological Survey: Washington, DC, USA, 2010.

45. Andrews, P.; Bevins, C.; Seli, R. BehavePlus Fire Modeling System, Version 4.0: User's Guide; U.S. Department of Agriculture, Forest Service, Rocky Mountain Research Station: Fort Collins, CO, USA, 2008.

46. Bradshaw, L.; Deeming, J.; Burgan, R. The 1978 National Fire-Danger Rating System; U.S. Department of Agriculture Forest Service, Intermountain Forest and Range Experiment Station: Ogden, UT, USA, 1978.

47. Burgan, R. 1988 Revisions to the 1978 National Fire-Danger Rating System; U.S. Department of Agriculture Forest Service, Southeastern Forest Experiment Station: Asheville, NC, USA, 1988.

48. Deeming, J.; Burgan, R.; Cohen, J. The National Fire-Danger Rating System-1978; U.S. Department of Agriculture Forest Service, Intermountain Forest and Range Experiment Station: Ogden, UT, USA, 1977.

49. Finney, M. FARSITE: Fire Area Simulator-Model Development and Evaluation; Department of Agriculture, Forest Service, Rocky Mountain Research Station: Ogden, UT, USA, 2004.

50. DRI. Historical Fire Weather Data for FPA. Desert Research Institute. Available online: https://wrcc.dri.edu/ fpa/ (accessed on 1 March 2015).

51. IPCC. Climate Change 2013: The Physical Science Basis; Intergovernmental Panel on Climate Change, Cambridge University Press: Cambridge, UK; New York, NY, USA, 2013.

52. Baeza, M.J.; De Luís, M.; Raventós, J.; Escarré, A. Factors influencing fire behaviour in shrublands of different stand ages and the implications for using prescribed burning to reduce wildfire risk. J. Environ. Manag. 2002, 65, 199-208. [CrossRef] [PubMed]

53. Cooper, S.; Lesica, P.; Kudray, G. Post-Fire Recovery of Wyoming Big Sagebrush Shrub-Steppe in Central and Southeast Montana; The United States Department of the Interior, Bureau of Land Management, State Office: Helena, MT, USA, 2007.

54. West, N.; Hassan, M. Recovery of sagebrush-grass vegetation following wildfire. Rangel. Ecol. Manag. 1985, 38, 131-134.

55. Gao, F.; Masek, J.; Schwaller, M.; Hall, F. On the blending of the Landsat and MODIS surface reflectance: Predicting daily Landsat surface reflectance. IEEE Trans. Geosci. Remote Sens. 2006, 44, 2207-2218.

56. Zhang, X.; Wang, J.; Henebry, G.M.; Gao, F. Development and evaluation of a new algorithm for detecting 30 $\mathrm{m}$ land surface phenology from VIIRS and HLS time series. ISPRS J. Photogramm. Remote Sens. 2020, 161, 37-51. [CrossRef]

57. Zhu, X.; Chen, J.; Gao, F.; Chen, X.; Masek, J.G. An enhanced spatial and temporal adaptive reflectance fusion model for complex heterogeneous regions. Remote Sens. Environ. 2010, 114, 2610-2623. [CrossRef] 
58. Gao, F. Integrating Landsat with MODIS products for vegetation monitoring. In Satellite-Based Applications on Climate Change; Qu, J., Powell, A., Sivakumar, M.V.K., Eds.; Springer: Dordrecht, The Netherlands, 2013; pp. 247-261.

59. Homer, C.; Dewitz, J.; Fry, J.; Coan, M.; Hossain, N.; Larson, C.; Herold, N.; McKerrow, A.; VanDriel, J.N.; Wickham, J. Completion of the 2001 national land cover database for the conterminous United States. Photogramm. Eng. Remote Sens. 2007, 73, 337-341.

(C) 2020 by the authors. Licensee MDPI, Basel, Switzerland. This article is an open access article distributed under the terms and conditions of the Creative Commons Attribution (CC BY) license (http://creativecommons.org/licenses/by/4.0/). 